Pamiętnik Literacki 2016, 3, s. 139-154
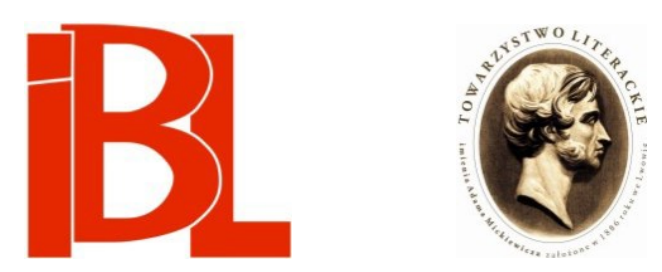

Mroki przyszłości. O nurcie tzw. dark future w polskiej fantastyce naukowej

Adam Mazurkiewicz 


\section{MROKI PRZYSZŁOŚCI O NURCIE TZW. DARK FUTURE W POLSKIEJ FANTASTYCE NAUKOWEJ}

Rozkwit technologii, a jednocześnie świadomość potencjalnych niebezpieczeństw wynikających z jej niewłaściwego wykorzystania sprawiaja, iż twórczość fantastycznonaukowa, przywołująca nierzadko mit postępu, bywa postrzegana jako zbeletryzowana forma refleksji nad rozwojem i przyszłym kształtem cywilizacji. Oczywiście, nie popełniając nadużycia intelektualnego, można tym mianem określić prozę jedynie nielicznych autorów. Najczęściej bowiem pisarze zwykli ograniczać wizje fantastycznonaukowe do obrazów bądź rajów technologicznych, bądź też takich piekieł. Co znamienne, zdecydowanie mniej jest opowieści projektujących przyszłe losy człowieka w tonacji optymistycznej. Technologiczne infernum zdaje się pociagać twórców science fiction w stopniu nieporównanie większym niż „nowy, wspaniały świat” powszechnej szczęśliwości.

Zarazem nieomal za regułę należy uznać, iż wątek zagłady w fantastyce naukowej jest wartością samoistną, autorzy zaś futurystycznych fabuł tylko dla rozrywki sięgają po motywy zagrożenia ze strony techniki. Sytuacja ta występuje najczęściej, jednakże praktyka czytelnicza sugeruje, iż science fiction nie musi być „skazana” na miałkość intelektualną. Toteż szczególna predyspozycja fantastyki naukowej do wykorzystywania żywionych przez odbiorców (niekiedy podświadomych) obaw przed upadkiem dotychczasowego porządku sprawia, że trudno jednoznacznie oceniać zdolność tej prozy do wyrażania niepokojów cywilizacyjnych.

Możliwości rozpatrywania kwestii tego rodzaju przez fantastykę ambiwalentnie oceniał Stanisław Lem, piszący:

[...] Science Fiction, jakkolwiek byłaby tandetna, sięga eschatologicznej problematyki, która nie jest wyssana $\mathrm{z}$ palca. Więc w pewnym sensie stoi bliżej prawdy i niejako bardziej może być realistyczna od prozy typu „mitologicznego realizmu” [...]. Science Fiction fałszywymi tonami opowiada o tym, co już treściowo fałszem być nie musi; stąd jej dwuznaczność jako arywisty lekceważonego, ale porastającego w siłę - nie najsympatyczniejszym ze sposobów, bo ma nieco szantażowy charakter skwapliwość, z jaką nas ona [tj. SF] częstuje końcami świata ${ }^{1}$.

Problematyka eschatologiczna, na której przykładzie Lem rozważa pożytki płynące $z$ lektury fantastyki naukowej, zyskała szczególny wymiar w obliczu wyścigu zbrojeń i zagrożenia konfliktem nuklearnym po drugiej wojnie światowej. Wszak niebezpieczeństwo rozpoczęcia działań militarnych z użyciem arsenału atomowego

1 S. Le m, Fantastyka i futurologia. Wyd. 2. T. 2. Kraków 1973, s. 8-9. 
stało się po roku 1945 faktem dotyczącym całej ludzkości, bez względu na miejsce zamieszkania i wyznawana ideologię. Próby „oswojenia” sytuacji permanentnego niepokoju sprawiły, że do fantastyki katastroficznej przeniknął pierwiastek czarnego humoru. Znajdował on wyraz bądź - jak np. w przypadku filmu Stanleya Kubricka Doktor Strangelove, czyli jak przestałem się martwić i pokochałem bombę ${ }^{2}$ - w groteskowym ujęciu rozpatrywanych kwestii, bądź też w ludycznym stosunku do niebezpieczeństwa atomowego kataklizmu, po jakim nastapi epoka „nowego barbarzyństwa" wraz z kultem siły. Jednoznacznie negatywną ocenę tendencji do zabawy strachem przed konfliktem nuklearnym wyrażał Lem. Według autora Fantastyki i futurologii - skąd pochodzi opinia, którą chcemy tu zacytować:

nienasyconym fantastom groza realnie wisząca nad światem najwyraźniej nie wystarcza. W tym rysie ich twórczości manifestuje się nie tyle jakowyś demonizm, ile raczej - „ludyczny” stosunek do atomowego niebezpieczeństwa: powitali je jako nową szansę budowania historii niezwykłych i wstrząsających ${ }^{3}$.

Co znamienne, prozaicy ci kreślą opowieści nie po to, by przestrzegać, lecz po to, by bawić.

Jako przykład podajmy dwa filmy, będące niegdyś kinowymi sensacjami: Ostatni brzeg Stanleya Kramera ${ }^{4}$ oraz Mad Max George'a Millera ${ }^{5}$. Dwie dekady dzielące te produkcje zaważyły nie tylko na rozłożeniu akcentów fabularnych, lecz przede wszystkim na zmianie stosunku do niebezpieczeństwa nuklearnego. Dla Kramera wojna $\mathrm{z}$ użyciem arsenału atomowego była pretekstem do refleksji na temat ludzkich zachowań w „dniach ostatnich”. Australia - jedyny kontynent, do którego nie dotarło jeszcze skażenie - stała się tytułowym „ostatnim brzegiem” dla nielicznych ocalałych, świadomych kruchości własnej egzystencji i nieuchronności śmierci. Reakcje na ową konieczność nadejścia toksyn i związanego z tym kresu ludzkości ukazywane są w stonowanej scenerii, do złudzenia przypominającej życie codzienne widza ${ }^{6}$. Odbiorcy, którzy oczekiwali w filmie Kramera monumentalnych wizji katastrofy, mogli odczuć zawód. Reżyser bowiem skupił się na obrazie ludzi stara-

2 Doktor Strangelove, czyli jak przestałem się martwić i pokochałem bombę (Dr Strangelove, or How I Learned to Stop Worrying and Love the Bomb). Reż. S. Ku b r i c k. USA - Wielka Brytania 1964.

3 Le m, op. cit., t. 2, s. 11.

4 Ostatni brzeg (On the Beach). Reż. S. Kra mer. USA 1959. Scenariusz J. P ax to n a oparty na powieści N. Shute'a pod tym samym tytułem.

5 Mad Max. Reż. G. Mille r. USA 1979. Widowisko Millera znalazło dopełnienie w kolejnych filmach, tworzacych cykl połączony postacią tytułowego bohatera: Mad Max 2. Wojownik szos (Mad Max 2: Road Warrior). Reż. G. Mill e r. Australia 1981; Mad Max 3. Pod Kopułą Gromu (Mad Max 3: Beyond Thunderdome). Reż. G. Mille r, G. O gilvi e. Australia 1985; Mad Max. Na drodze gniewu (Mad Max: Fury Road). Reż. G. Mille r. Australia-USA 2015.

6 Ową Kramerowska tradycję opowiadania o zagładzie atomowej w stonowany, kameralny sposób kontynuują jedynie nieliczni twórcy. Pragną oni - podobnie jak reżyser Ostatniego brzegu- uczynić wizję nuklearnej pożogi pretekstem do studium psychologicznego jednostki w obliczu nieuchronnej śmierci. Jako przykład przywołajmy Testament (The Testament. Reż. L. Littma n. USA 1983). Fabuła filmu koncentruje się wokół losów małomiasteczkowej rodziny, żyjącej w Kalifornii. Littman nie ukazuje samego momentu ataku, skupiając się na procesie rozpadu związków międzyludzkich, spowodowanego świadomością nieuniknionego kresu własnego życia. Zdaniem J. Skwary (Sezon smutnego kosmity. Warszawa 1988, s. 57), „Film [...] sprawia ogromne wrażenie swoją prostotą i monotonią. Gdyby nie informacja, że mamy do czynienia z nuklearną zagładą, nie wiedzielibyśmy, o co chodzi. Autorka wychodzi z założenia, że nie spadające bomby budzą grozę. [...] Okrop- 
jących $z$ godnością odnaleźć się w sytuacji bez wyjścia ${ }^{7}$. Po premierze francuski krytyk, Michael Capdenac, pisał:

Brak tu [tj. w filmie Kramera] galopującego konia Apokalipsy. Nie ma sądu ostatecznego. Ale śmierć atomowa także nie ma oblicza. Jest głucha, niema, niewidzialna. Jest wszędzie, niszcząc bezwzględnie ludzkie istnienie, nie szczędząc nikogo, nawet tych, którzy znajdowali się poza walką... Ani razu nie zobaczyliśmy ofiar w scenerii fałszywych katastrof, a przecież nigdy w takim stopniu nie władał jeszcze ekranem strach ${ }^{8}$.

To, co Jean Baudrillard nazywa interwencyjną mocą kina ${ }^{9}$ - sprawdzanie, jaką siłe oddziaływania ma film - wykorzystane przez Kramera do stworzenia paraboli, Miller w cyklu opowieści o herosie postapokaliptycznego świata, tytułowym Mad Maxie, obrócił w zabawę. Produkcje tego drugiego reżysera (i jego naśladowców) stanowią sprawnie zrealizowane kino fantastyczno-przygodowe, a element science fiction służy w nich uatrakcyjnieniu fabuły. W analogiczny sposób można rozpatrywać cele przyświecające autorom współczesnej odmiany fantastyki katastroficznej. Wykorzystują oni obrazy przyszłych kryzysów (wśród których dominują wątki konfliktu nuklearnego, choć nie tylko one) do snucia opowieści o ostatnich dniach ludzkości. Opowieści te tworzą specyficzny nurt w obrębie science fiction, określany mianem dark future.

Nazwę ową można tłumaczyć jako 'mroczna/ponura/posępna przyszłość', co - zgodnie z zamierzeniami prozaików - ma mówić o charakterze odzwierciedlanego czasu. Innymi słowy, dark future ukazuje uniwersum, które da się opisać w następujący sposób: „mroczne siły w cieniu, wróg u bram, ciągle wojny, realistyczne [!] oddawanie świata" ${ }^{10}$. Zakreślony w przywoływanym tu cytacie krag tematyczny interesujący autorów dark future pozwala na utożsamienie go z dziełami przedstawiającymi rzeczywistość po globalnym kryzysie. Na gruzach przeszłości ostatni reprezentanci rasy ludzkiej usiłują odbudować struktury społeczne.

Gwoli rzetelności należy wszakże przyznać, iż takie rozumienie nazwy nurtu nie jest jedynym możliwym. Lektura treści zawartych na stronach internetowych (zwłaszcza dotyczacych gier Cyberpunk 2020 i Fallout $I^{11}$ ) wskazuje, iż wypowiadający się na temat owych gier nader często odnoszą określenie „dark future” również do fantastyki cyberpunkowej, tj. podejmującej kwestie tożsamości człowieka żyjącego w przestrzeni zdominowanej przez technologie komputerowe. Jednak w opinii piszącego te słowa rozumienie terminu zaproponowane na wspomnianych tu forach internetowych wydaje się zbyt szerokie i sprawia, że staje się on migotli-

ne jest tylko powolne umieranie bez nadziei na pomoc. I wreszcie świadomość, że przestało się być wrażliwym na ludzki gniew i rozpacz. Najpierw umierają uczucia, potem dopiero ciało".

7 Zob. A. Koł odyń s ki, Filmy fantastyczno-naukowe. Warszawa 1972, s. 88.

8 Cyt. jw.

9 J. B a udrillard, Czas apokalipsy. W: Symulakry i symulacja. Przeł. S. Królak. Warszawa 2005, s. 75.

10 Gr u s z c zy, wypowiedź w dyskusji: Czy Monastyr jest światem dark fantasy? Forum „Poltergeist”. Na stronie: http://forum.polter.pl/viewtopic.php?t=1429\&start=60 (data dostępu: 15 VII 2016).

11 Dodajmy jedynie, iż druga z przywołanych tu produkcji nie jest w ścisłym sensie cyberpunkowa, $\mathrm{w}$ trakcie rozgrywki napotyka się wszakże postacie o takiej proweniencji - androidy, sztuczną inteligencję, funkcjonująca w zapomnianym superkomputerze, ludzi wspomagających się protezami i wszczepami, które przekształcają ich w cyborgi. 
wy znaczeniowo. Podobnie mylne byłoby utożsamianie dark future $\mathrm{z}$ formami kontrutopii (antyutopią i dystopia). Wprawdzie science fiction ukazujacca mroczną przyszłość wywodzi się z fantastyki społecznej, odmienne jest wszakże w tym przypadku rozłożenie akcentów fabularnych. Twórcy utopii negatywnych zainteresowani są bowiem mechanizmami społecznymi prowadzacymi do dehumanizacji i reifikacji jednostki. Tymczasem autorzy opowieści dark future traktuja społeczeństwo przyszłości (czy raczej jego namiastkę) wyłącznie jako scenerię dla perypetii fabularnych. Innymi słowy, pytanie: „Co może doprowadzić do katastrofy?”, zastępują oni innym: „Jak wygląda świat po kataklizmie?”. Oczywiście, istnieją utwory łączące refleksję społeczną $\mathrm{z}$ poetyką znamienną dla dark future (np. Dziennik czasu plagi Andrzeja Ziemiańskiego lub Bramy strachu Emmy Popik), nie sa one jednak reprezentatywne dla omawianego zjawiska.

Śledzac ewolucję XX-wiecznych apokaliptycznych prognoz społecznych ujętych w ramy fikcji literackiej, można dostrzec analogię między dziejami modernistycznej i międzywojennej fantastyki katastroficznej a jej współczesną odmianą. Paralele wynikają $z$ tożsamości mechanizmów społecznych wpływających na ową twórczość. Różne są, oczywiście, źródła natchnienia. Nurt młodopolskiej i międzywojennej fantastyki katastroficznej wywodził się z charakterystycznego dla tego okresu poczucia schyłkowości; był reakcją literacka (głównie w obiegu popularnym) na prognozy wieszczące kres świata, koniec hegemonii białego człowieka. Wyrażając świadomość fin de siècle’u, kontaminował ją z zyskującą poczytność u schyłku XIX wieku na terenach zaborów, przede wszystkim pruskiego i austriackiego, literatura jarmarczną. Jej autorzy, owi „Nikiforowie pióra” ${ }^{12}$, wpłynęli w istotny sposób na recepcję teorii Oswalda Spenglera, Miguela de Unamuno i innych filozofów, przepowiadających koniec człowieka. Jednocześnie zaś przyczynili się do rozwinięcia się w Dwudziestoleciu międzywojennym zapotrzebowania na fantastykę katastroficzną w jej różnych odmianach. Dostosowanie owych wizji do oczekiwań masowego odbiorcy sprawiło, że wielości obrazów ostatnich godzin ludzkości nie towarzyszyła pogłębiona refleksja nad prezentowanymi mechanizmami społecznymi. Toteż do wyjątków należą powieści sięgające do fantastyczno-apokaliptycznej rekwizytorni, by traktować ją w sposób pretekstowy, jak czynią Stanisław Ignacy Witkiewicz w Pożegnaniu jesieni i Nienasyceniu, Bogusław Adamowicz w Triumfie żółtych lub Antoni Słonimski w Dwu końcach świata.

Charakterystyczna cechą dark future - zwłaszcza najnowszej prozy autorów wykorzystujacych poetykę tego nurtu - jest mało wyrafinowane nawiązywanie do założeń katastrofizmu Dwudziestolecia międzywojennego. W utworze Roberta J. Szmidta Apokalipsa według Pana Jana (2003) można zauważyć próbę reinterpretacji i dostosowania do współczesnej świadomości nieomal wszechobecnych w literaturze tamtego okresu - zarówno popularnej, jak i wysokoartystycznej - motywów, pośród których niebagatelne miejsce zajmował obraz wojny totalnej i zagrożenia tzw. żółtym niebezpieczeństwem.

Nie należy zarazem zapominać o istotnej różnicy w motywacji wykorzystywanych wątków katastroficznych. Pisarze publikujący w Dwudziestoleciu traktują podej-

12 Określenie J. D u ni n a (Papierowy bandyta. Książka kramarska i brukowa w Polsce. Łódź 1974, s. 6). 
mowane kwestie bądź doraźnie, jako formę zbeletryzowanej publicystyki, bądź też jako okazję do przeprowadzenia eksperymentu myślowego. Szmidt natomiast podporządkowuje owe wątki funkcji ludycznej. O ile powieści Stefana Barszczewskiego lub Mieczysława Smolarskiego dają świadectwo literackie autentycznej obawie przed skutkami ataku bronią masowego rażenia (za jaką uznano po pierwszej wojnie światowej gazy bojowe), o tyle Szmidt „bawi się” zagrożeniem nuklearnym.

Literackich źródeł wydarzeń składających się na fabułę powieści Szmidta są świadomi jej bohaterowie, podsuwający ten trop interpretacyjny czytelnikowi - jeden $z$ prominentów $z$ otoczenia Sobieszczuka sugeruje: „Być może mamy do czynienia $z$ [...] zapowiadanym w przepowiedniach zalewem żółtej rasy" ${ }^{13}$. Podobny pierwowzór (można tu przywołać np. Czandu Barszczewskiego) mają obrazy migracji Chińczyków, zasiedlajacych opustoszałe tereny wschodniej Europy. Porównajmy opisy owej wędrówki ludów:

mienią się barwami tęczy kaftany i chałaty, żupany i bluzy Mongołów, Buriatów, Kałmuków, Kirgizów, Tatarów, plemion chińskich, tybetańskich i malajskich [...]; połyskuje stal krzywych szabel tatarskich [...]; migają buzdygany i buławy; śród papach i kołpaków strzela tu i ówdzie misiurka lub szyszak, a nawet kolczugi i karaceny starodawne okrywają niejedną pierś pod lasem sztandarów, buńczuków i godeł najrozmaitszych, szeleszczących pieśni bahadurów.

Zdawałoby się, że cała Azja [...] przywdziała odwieczny strój symboliczny wielkich przodków, by krasą barbarzyńską olśnić Europę ${ }^{14}$.

Każdy z trzech członów nadchodzącej armii liczył od dwudziestu sześciu do trzydziestu tysięcy żołnierzy. Każdy posiadał wsparcie niemal stu czterdziestu dział średniego i dużego kalibru oraz stu lekkich wozów bojowych, transportowanych teraz w zaprzęgach wołów czy też innych rogatych zwierząt. $[\ldots]$

[...] Na wypalonych stepach Kazachstanu i u podnóża Uralu kamery [...] zarejestrowały ogromne masy ludzi, wędrujących w kierunku żyznych równin Europy. Miliony Chińczyków szły pieszo, niekiedy $z$ dobytkiem, w poszukiwaniu ziemi obiecanej. Wielu zostawało w napotkanych miejscowościach, w miejscach oszczędzonych przez wojnę, ale ta ludzka rzeka zdawała się nie mieć końca ${ }^{15}$.

W pierwszej z przytoczonych tu powieści Azja została zaprezentowana jako siła przechowująca pierwotną witalność, przeciwstawiona wygodnemu życiu jednostki wyrosłej w zachodniej cywilizacji. Odpycha swym prymitywizmem, pociągając zarazem egzotyką. Lektura zarówno tego, jak i drugiego $\mathrm{z}$ fragmentów pokazuje głównie anonimowość masy najeźdźców. Zmienia się wprawdzie broń (w powieści Barszczewskiego wykazuje ona bardziej anachroniczny charakter niż ta, która dysponują Polacy, co ma poświadczać zacofanie cywilizacyjne agresora), lecz konfrontacja w obu przypadkach jest nieunikniona.

Owe nawiązania do tradycji modernistyczno-międzywojennej fantastyki katastroficznej nie muszą - jak w Apokalipsie według Pana Jana Szmidta - być wyrażane expressis verbis. Za przykład ukrytych, niekiedy bezwiednych nawet dla twórcy, powinowactw literackich może służyć motyw miasta - ostatniej enklawy minionego porządku. Zarówno w przedwojennej, jak i we współczesnej fantastyce katastroficznej miejska aglomeracja zdaje się pełnić dwie funkcje: poświadcza upadek cywili- 
zacji oraz stanowi wymierne, fizyczne uobecnienie pamięci o przeszłości. W tej roli występują anonimowa enklawa w Bramach strachu Popik oraz Wrocław w Autobahn nach Poznań Ziemiańskiego. Utwory te łączy też postać obcego; przybysza, z którego perspektywy czytelnik postrzega miasto jako coś nierealnego. Tym bardziej że nie każdemu dane jest w nim zamieszkać - w Bramach strachu bohater ten w ciagu trzech dni musi znaleźć pracę; w opowiadaniu Ziemiańskiego:

sztucznie winduje [się] ceny i pensje na niebotyczne wyżyny, żeby nikt nie przyjeżdżał [...]. [...] żeby nie nazywano nas [tj. mieszkańców powieściowego Wrocławia] ksenofobami i rasistami, to my nikomu nie odmawiamy prawa do osiedlenia się, tyle tylko, że nikogo nie stać na życie we Wrocławiu ${ }^{16}$.

Dlatego też jedynie wrocławianie ze stałą praca „Mają perspektywę normalnego życia, o której reszta świata może jedynie czytać w starych powieściach" ${ }^{17}$.

Szczególnie sugestywnie został ukazany obraz miasta w Hordzie Piotra Górskiego. Stolica, widziana ze wzgórza, jest „ogromna”. Ma „kilka kilometrów średnicy, a obwarowania [...] [wznosza] się ponad ziemię na jakieś dwadzieścia metrów. Miasto [płonie] miliardem świateł w bladym mroku zbliżającego się wieczoru" ${ }^{18}$.

Owa wspólnota funkcji motywu miasta pozwala łączyć Ostatnia godzinę Tadeusza Konczyńskiego (1913; dalsze wydania pt. Koniec świata) i Miasto Światłości Smolarskiego (1924) ze współczesnymi opowieściami dark future (np. Bramami strachu Popik, Horda Górskiego, Apokalipsa według Pana Jana Szmidta). Zarazem jest świadectwem stałości określonych rozwiązan fabularnych, aktualizowanych na różne sposoby, zależne od kontekstu historyczno-społecznego.

Rozpatrując dark future na tle jej modernistyczno-międzywojennej poprzedniczki ideowej, nietrudno dostrzec analogiczne mechanizmy rządzące powstaniem analizowanego tu nurtu i wpływające na jego postać. Do rozwoju modernistycznej fantastyki przyczyniła się, o czym wspominaliśmy, fascynacja zapowiedziami kresu cywilizacji europocentrycznej. W przypadku dark future swoistym „społecznym detonatorem", umożliwiającym narodziny osobnego nurtu fantastyki katastroficznej, było narastające w latach siedemdziesiątych ubiegłego wieku zauroczenie punk rockiem, będącym najbardziej wyrazistym, prócz mody, przejawem subkultury punkowej. Gino Castaldo upatruje przyczyn fascynacji punkiem w rozczarowaniu młodego pokolenia Brytyjczyków połowy wspomnianej dekady wynikającym z recesji gospodarczej i gwałtownie zwiększającego się bezrobocia ${ }^{19}$. Omawiając fenomen punk rocka na przykładzie twórczości Sex Pistols, Slits i Clash, wskazuje on upo-

A. Zi e miańs ki, Autobahn nach Poznań. W: Zapach szkła. Lublin 2004, s. 444.

Ibidem, s. 445.

P. Gó r s ki, Horda. „Nowa Fantastyka” 1992, nr 11, s. 51.

Ówczesna sytuacja społeczno-polityczna była najważniejszym ze źródeł punk rocka, lecz nie jedynym. Należy bowiem odnotować, iż terminu „punk” w odniesieniu do muzyki rockowej używano od połowy lat sześćdziesiątych XX wieku, określając w ten sposób amatorskie zespoły, przedstawicieli tzw. rocka garażowego. Dekadę później miano punku zaczęto stosować do Television i Patti Smith Group. Ich piosenki bezpośrednio inspirowały następnych twórców punku. Wolno rzec, iż dzięki tym zespołom słowo „punk” nabrało dzisiejszego znaczenia. Muzyczne inspiracje autorzy punk rocka czerpali jednak nie tylko ze stylistyki garażowej. Istotne stały się dla nich dokonania The Velvet Underground, zaangażowanych politycznie The Stooges lub MC5 oraz niektórych grup glamrockowych. Punk rock można traktować również jako propozycję alternatywną w stosunku do grup rockowych, oskarżanych o przerost formy nad treścią i rezygnację z własnych ideałów na 
litycznienie przesłania muzyki jako najważniejszą (by nie rzec: dystynktywną) cechę nurtu $^{20}$.

Utwory punkowe odwoływały się do tradycji społecznie zaangażowanych hippisowskich „protest songów”. Co znamienne - a czego świadomość jest istotna w lekturze fantastyki dark future - nie zawierały one, w przeciwieństwie do pieśni „dzieci kwiatów”, akcentów pozytywnych. Punk, programowo negujacy wszelkie wartości, nie usiłował zastąpić ich innymi. Pustce aksjologicznej towarzyszył w nim nihilizm etyczny i społeczny, sprzeciw zaś wobec status quo stał się wartością samoistną. Postawa taka współgrała z przesłaniem punku, którego początkowym założeniem było odrzucenie jakichkolwiek ideałów. Ów wszechogarniający sprzeciw wobec tego, co zastane, w miarę upływu czasu przekształcił się w ruch społeczno-polityczny, wymierzony przeciwko instytucjom: rządowi i jego aparatowi przymusu (tj. policji i wojsku), zorganizowanym ruchom religijnym, środkom masowego przekazu, wielkim korporacjom itp., gdyż - według członków subkultury - ograniczają one wolność i niezależność człowieka. To właśnie negacja wszelkich form władzy doprowadziła do przyjęcia przez znaczną część punków ideologii anarchistycznej w jej licznych odmianach.

Punk, początkowo traktowany w Polsce jako chwilowa moda, dość szybko przekształcił się w zjawisko subkulturowe, dynamicznie rozwijające się do połowy lat osiemdziesiątych XX wieku ${ }^{21}$. Jednakże, mimo iż muzyka ta zyskała wielu zwolenników (co znamienne, nie wywodzili się oni - w przeciwieństwie do swych brytyjskich poprzedników - jedynie z niższych warstw społecznych), nie można mówić o rodzimej specyfice tego zjawiska. Wynika to zapewne $z$ charakteru punku, odrzucajacego współczesność bez względu na wszelkie podziały ideologiczne, klasowe itp. ${ }^{22}$

rzecz sukcesu komercyjnego (szerzej zob. Punk rock. Na stronie: http://pl.wikipedia.org/wiki/ Punk_rock (data dostępu: 15 VII 2016〉).

Zob. G. C a s t ald o, Ziemia obiecana. Kultura rocka (1945-1994). Przeł. J. U s zy ń s ki. Kraków 1997 (tu zwłaszcza rozdz. Punk. Nazajutrz po katastrofie). Możliwa jest, oczywiście, również inna interpretacja źródeł punku. Zdaniem T. Th o r n e'a (Mody, kulty, fascynacje. Słownik pojęć kultury postmodernistycznej. Przeł. Z. B a t k o. Wyd. 2. Warszawa 1999, s. 277-278), „Ruch punków był nie tyle ekspresją lęków i rozpaczy młodych bezrobotnych ludzi wywodzących się z klasy robotniczej, ile raczej nerwową reakcją okresu dojrzewania - wrażliwy, nieprzystosowany młody człowiek wkraczał w świat dorosłych, przybierając doprowadzoną do karykatury pozę skrajnego nihilizmu".

21 Oczywiście, i dziś powstają zespoły sięgające do tradycji punku, np. Zabili Mi Żółwia lub Farben Lehre. Ich repertuar nie ma jednak wydżwięku społecznego, charakterystycznego dla pierwotnej ideologii punk rocka. Są to grupy raczej stylizujące swoje utwory na punkowe niż w ścisłym sensie punkrockowe. Fakt ten nie oznacza wszakże, iż wypracowana przez autorów punku „estetyka krzyku" przeminęła. Jej elementy można bowiem, podobnie jak poetykę i światopogląd, odnaleźć współcześnie w hip-hopie (np. w piosenkach zespołów Warszafski [!] Deszcz, Wzgórze Ya-Pa 3, ERKA). W utworze Wzgórza Ya-Pa 3 Zabić ten hałas (na płycie: Osiedle pełne rymów, czyli HIP HOP jak okiem sięgnać, utwór 7) pojawiają się słowa:

Kogo drażni hip-hop ten drażni mnie

[.......]

Zrozum to

Najlepiej od zaraz

Nie ma możliwości

Żeby zabić ten hałas.

Jedynie niekiedy, jak w przypadku utworu Hans Kloss zespołu Dzieci Kapitana Klossa, można 
Jako przykład punkowego uniwersalizmu doświadczenia warto przywołać utwory zespołów Ałma-Ata (Fast), Kultura (Żyję $w$ tym mieście), Fort BS (Ty, Tytut niepotrzebny), KSU (Ewolucja 〈w ścieku〉, Jabolowe [!] ofiary, Rozkaz). Ukazywany jest w nich rozkład społeczeństwa, traktowanego jako anonimowa struktura.

Podobnie doświadczenie kompromitacji dotychczasowych wartości prezentowali autorzy pierwszych utworów dark future. Dość szybko jednak to, co stanowiło zbeletryzowany zapis upadku cywilizacyjnego, stało się zabawą w makabrę. Punkowe radykalizm i nihilizm ze światopoglądów przekształciły się w pozę. Twórcy przedstawiający mroczną przyszłość sięgnęli po rekwizytornię zjawiska wyrosłego na gruncie punk rocka, jednakże niezaangażowanego społecznie - heavy metalu.

Mariaż obu kierunków wprowadził do kultury masowej gloryfikację rozkładu i rozchwianie aksjologiczne rzeczywistości. Negowanie wszelkich wartości i norm społecznych, charakterystyczne dla punk rocka, problematyzował nurt nu metalu. Należący doń twórcy (zespoły Tool, Nine Inch Nails, wokalista Marilyn Manson) sięgnęli do poetyki skandalu, przywołując i parodiując sferę sacrum oraz naruszając tabu obyczajowe. Ów wybór tematyki świadczy - zdaniem Lesława Halińskiego - „o narastającej wśród młodzieży świadomości życia w świecie "odczarowanym", wyzutym z tradycyjnej metafizyki [...]"23. Na kryzys wartości fikcyjnego świata przedstawionego - co zdaje się sugerować Haliński w odniesieniu do twórczości numetalowej - istotny wpływ miała rzeczywistość pozatekstowa. Podobne zależności można odnaleźć również między kreacją artystyczną a stosunkiem do świata realnego w nurcie dark future. Charakteryzując związki heavy metalu $\mathrm{z}$ fantastyką, Jan Rutkowski sugerował, iż cechą wspólną obu przejawów kultury popularnej jest niezgoda na rzeczywistość, pociagająca za soba „nastroje dekadenckie, katastrofizm, pesymizm, agresję" ${ }^{24}$. W odczuciu piszącego te słowa uogólniający ton uwag Rutkowskiego nie oddaje stanu faktycznego. Jeśliby bowiem odrzucenie rzeczywistości utożsamiać - w odniesieniu do fantastyki naukowej - z postawą agresywną bądź dekadencka, prowadziłoby to do nadinterpretowania lub absurdalności odczytan wielu utworów np. $\mathrm{z}$ kręgu fantastyki socjologicznej.

Należałoby również rozpatrzyć, czy w istocie każdorazowo wolno mówić o bezradności literatury realistycznej, ilekroć pisarz zechce - z różnych względów - „przyoblec" swe dzieło w kostium fantastyczny. Bliższe prawdy wydaje się, iż wspomniane przez Rutkowskiego nastroje (p o zy?) można odnaleźć przede wszystkim w mało wartościowych pod względem artystycznym i myślowym utworach, w których elementy te odwracają uwagę od jałowości podejmowanych kwestii. Baczna lektura tekstów z kręgu dark future obnaża sygnalizowane tu mechanizmy markowania

mówić o aktualizacji rodzimego bohatera z kręgu kultury popularnej, w Chodź, pójdziemy tam Nocnych Szczurów zaś - o przywołaniu polskiej scenerii (cyt. za: „Okolice” 1987, nr 3, s. XVI):

Dziś spotkamy się w „Remoncie”

Albo w gdańskim „Rudym Kocie”

Jeśli chcesz to w Wielkim Młynie

Lub gdzieś dalej w Jarocinie. a ciałem. A po co nam rock. Red. W. J. Burszta, M. Rychlewski. Warszawa 2003, s. 237. 
rozterek egzystencjalnych egzaltowaną stylistyką i zastępowania istotnych zagadnień społecznych - frazesami.

Ze względu na to, że w opracowaniach literatury popularnej o charakterze leksykonów - nasuwają się tu na myśl Leksykon polskiej literatury fantastycznonaukowej Andrzeja Niewiadowskiego i Antoniego Smuszkiewicza (1990) oraz Słownik literatury popularnej pod redakcją Tadeusza Żabskiego (1997; wyd. 2, poprawione i uzupełnione: 2006) - brak haseł omawiajaccych analizowany fenomen, na potrzeby niniejszego szkicu można zaproponować roboczą definicję dark future. Mianem tym zostanie określony nurt science fiction pokrewny fantastyce katastroficznej (wolno traktować go jako jej specyficzny przejaw), którego wyznacznikami są:

- czas akcji sytuowany w lub (częściej) po epoce globalnego kryzysu, wywołanego przez różnorodne czynniki;

- postapokaliptyczna (zwykle związana z wojną nuklearna) sceneria;

- nihilistyczna i radykalna postawa bohaterów wobec wyzwań rzeczywistości, wywodząca się z subkultury związanej z punk rockiem;

- apoteoza przemocy, traktowanej jako modus vivendi.

W dalszej części artykułu będą omówione owe wyróżniki.

\section{U źródeł upadku dotychczasowego porządku}

Najczęściej przyczyną rozkładu cywilizacji świata przedstawionego utworów z kręgu dark future jest wojna atomowa. Wystąpiła ona w bliższej lub dalszej przeszłości, przyczyniając się do zerwania ciągłości historycznej. Przykładem utworu, w którym konflikt nuklearny rozpoczyna nowe datowanie, jest nowela filmowa Piotra Szulkina Golem. Mówi ona o zdarzeniach rozgrywających się „W $41 \mathrm{roku}$, po ostatnim 268 niedoświadczalnym wybuchu nuklearnym [...]” ${ }^{25}$. Rozwiązanie to należy jednak traktować jako jednostkowe, najczęściej bowiem autorzy dark future poprzestaja (jak w przypadku Apokalipsy wedtug Pana Jana lub Autobahn nach Poznań) na wspomnieniu wojny nuklearnej jako faktu historycznego. Bohater innej noweli Szulkina, $O$ bi, o ba, stwierdza:

Rok temu skończyła się wojna. Rok? Chyba rok.

Nie zaglądam do kalendarza. Nikt nie zagląda. Gdy przestały wybuchać atomowe bomby, ponieważ wszystkie warte tego [tj. zniszczenia] cele zostały zniszczone, wyszliśmy z naszej betonowej skorupy ${ }^{26}$.

Na konieczność uwzględniania innych niż konflikt atomowy źródeł globalnego kryzysu wskazuje uczestnik dyskusji na forum internetowym posługujący się pseudonimem „Kret” 27. Odpowiadający mu internauta, podpisujący się jako Adam Waśkiewicz, wymienia następujące potencjalne przyczyny upadku cywilizacji:

- wojna i związany z nią kryzys społeczno-gospodarczy;

- zaraza dziesiątkująca populację;

- kataklizm naturalny;

P. Szulki in, Golem. W: „O bi, o ba” $i$ inne prawdziwe nowele filmowe. Warszawa 1984, s. 190.

P. Szulkin, $O b i, o b a$. W: jw., s. 87.

Kr et, wypowiedź w dyskusji Klimaty postapokaliptyczne. Forum „Gildia.pl”. Na stronie: http:// www.forum.gildia.pl/index.php?topic=1049.0 (data dostępu: 21 VII 2016). 
- powody nadnaturalne, prowadzące do pojawienia się demonów ${ }^{28}$.

Dyskusja, trwająca w okresie 20 I 2003 - 20 IX 2012, została zawieszona, nie przyniósłszy rozwiązań. Może jednak świadczyć o żywym zainteresowaniu internautów zjawiskiem dark future - zainteresowaniu stymulowanym zapewne premiera postapokaliptycznej gry Fallout (nb. tytuł ten przywołuje w swej wypowiedzi „Kret”).

\section{Sceneria akcji}

Świat przedstawiony w fantastyce dark future jest zunifikowany i służy jedynie podkreślaniu atmosfery towarzyszącej zagładzie ludzkości. Dlatego najczęściej akcja utworów nie rozgrywa się $\mathrm{w}$ industrialnym piekle betonowej dżungli miast przyszłości, lecz na gruzach aglomeracji. Jeśli nawet, jak w przypadku filmowego obrazu Manhattanu z Ucieczki z Nowego Jorku ${ }^{29}$ bądź Seattle z Klasy $1999^{30}$, widzowi zostaja zaprezentowane miejsca akcji lokowane w sposób pozwalający na odniesienie ich do rzeczywistości pozafikcyjnej, dochodzi nie do skopiowania, lecz do przetworzenia wzorca urbanistycznego. Ruiny, wraki zniszczonych samochodów na zdewastowanych ulicach, hordy ekstrawagancko ubranych mieszkańców miast mają przypominać oglądającemu, że jego wiedza na temat owych miejsc jest nieadekwatna do wizji futurystycznej.

Do reprezentatywnych dla dark future opisów przestrzeni należy ten zawarty w opowiadaniu Grzegorza Drukarczyka Reguła przetrwania:

Ogromne gmaszysko stacji dzielnie znosiło zgubny wpływ uciekającego czasu. Jedynie gdzieniegdzie duże płaty łuszczącego się tynku odsłaniały czerwona mozaikę ceglanego muru. [...] Okna, skrzywione w diabolicznym grymasie wybitych szyb [...]. Szeregi zwrotnic kryła karłowata roślinność. [...]

[...] rampa, czy właściwie stos spróchniałych desek po niej pozostałych, była lekko na uboczu [...] ${ }^{31}$.

W utworze Drukarczyka ukazany jest - charakterystyczny dla omawianego tu nurtu - czas postindustrialnego rozpadu cywilizacji technicznej, spowodowany bliżej nie określoną katastrofą. W Regule przetrwania zachwianiu ulega również struktura temporalno-spacjalna, co pozwala bohaterowi przenosić się do przeszłości. Dzięki swoistym „dziurom w czasie” może on zdobywać pożywienie i środki niezbędne do przeżycia.

Podobnie zarysowaną przestrzeń odnajduje czytelnik w opowiadaniach Popik, przedstawiającej wegetację ostatnich reprezentantów ludzkości:

dorośli umarli i świat należał do nas, do dzieci. Świeciło słońce, siedzieliśmy na krawężniku, wyciągnąwszy piszczele nóg na spękany asfalt jezdni. Nie mieliśmy siły rozmawiać, wiedzieliśmy, że nie dożyjemy niedzieli ${ }^{32}$.

Trzeba dodać, iż do wyjątków należy sytuacja, w której konflikt dotyczy jedynie

A. Waśkiewicz, wypowiedź w dyskusji (jw.). Osoba podpisująca się jako „ponury_jay” dodaje do przyczyn wymienionych przez Waśkiewicza niekontrolowany rozwój nanotechnologii (jw.). Ucieczka z Nowego Jorku (Escape from New York). Reż. J. Carpenter. USA - Wielka Brytania 1981.

$30 \quad$ Klasa 1999 (Class of 1999). Reż. M. L. Le s ter. USA 1989.

31 G. Drukarczyk, Reguła przetrwania. W: Reguła baśniowego mroku. Warszawa 1986, s. 29.

E. Po pi k, Nadejście Fortynbrasa. W: Tylko Ziemia. Warszawa 1986, s. 28. 
części kontynentu. W Śmierci Szczurołapa Jarosława Grzędowicza skonfrontowane zostały ogarnięty wojną Wschód i dostatni Zachód. Uciekinier z terenów działań wojennych, Kirosjan, pozostawił za soba „pachnące napalmem skaliste stepy, pomalowane na piaskowo, płaskie czołgi oblepione wyjącymi Rycerzami Islamu, płonące ruiny Erewańskiego Uniwersytetu, zgliszcza młodej Republiki Armeńskiej, patrole Specnazu [...]. [...] krew, dym, śmierć i trzy miesiące tułaczki” ${ }^{33}$. Z owa apokaliptyczną wizją kontrastuje obraz „rozświetlonej neonami, pachnącej wodą kolońską, sytej Zjednoczonej Europy" ${ }^{34}$.

Jednostkowość rozwiązania zastosowanego przez Grzędowicza wynika głównie z funkcji, jaką globalny charakter kryzysu pełni w nurcie dark future. Wszechobecność katastrofy przyczyniającej się do upadku cywilizacji w jej dotychczasowym kształcie akcentuje, iż kryzys ten jest niemożliwy do uniknięcia. $Z$ tego względu twórcy dark future, podobnie jak ich przedwojenni antenaci literaccy, kreśląc wizje mrocznej przyszłości, nie ograniczają się do wybranego obszaru, czyniąc (najczęściej implicite) mrocznym miejscem całą Ziemię.

\section{Bohater i jego postawa aksjologiczna}

Żyjący w świecie chaosu protagoniści dark future wegetują, zajmując się jedynie zaspokajaniem potrzeb fizjologicznych. Biologiczne przeżycie w świecie przyszłości staje się priorytetem, któremu jest podporządkowane wszystko inne. W Nadejściu Fortynbrasa Popik informacje umożliwiające przetrwanie bohaterów są skrzętnie ukrywane, by nikt nie mógł z nich skorzystać:

- Babcia powiedziała, że jedzenie robi się ze zwierząt i roślin. Ale zwierzęta trzeba zabić, by włożyć do puszki. Kazała mi powtarzać: zaostrz patyk, uderz kilka razy, mięso, życie.

$[\ldots]$

- Tamtym nie powiemy? - upewniłem się, a ona pokiwała głowa.

Zaostrzyć patyk, powtarzałem w myślach, uderzyć, poprawić, zabić, żyć3 35 .

Wszelkie sojusze zawierane są w imię wspólnych celów i rozpadają się po ich osiagnięciu. Partykularyzm motywacji takich działań wyraża Pat, bohater Reguły przetrwania Drukarczyka. Stwierdza:

Wspólnota interesów - to wszystko. Żadnego zaufania, żadnej miłości, żadnej pewności - żadnych bzdur. Tak musi być, jeśli chcesz żyć. [...] Bez uczuć - ten towar zwrócono producentowi. Za dużo reklamacji z trzeciego świata - ze świata umarlaków ${ }^{36}$.

Cynizm owej deklaracji jest jednakże świadectwem nie tyle wiary w siebie i siły wypowiadającego ją, ile jego bezradności w obliczu drapieżności świata, w którym nie obowiązują żadne umowy społeczne. Przetrwanie - bo trudno w tym przypadku mówić o poczuciu bezpieczeństwa - oznacza życie w ciągłym zagrożeniu:

J. G r zę d ow i c z, Śmierć Szczurołapa. W zb.: Wizje alternatywne. Antologia opowiadań „SF” pisarzy polskich. Wybór, oprac. W. S e d eń k o. Białystok 1990, s. 127. 
jestem [...] we własnym świecie, gdzie decydują ułamki sekund. Zbyt duże ryzyko. Nie czas na wypoczynek. [...] niewielkie spóźnienie będzie równoznaczne ze śmiercią $[\ldots]^{37}$.

Walka staje sie jedynym sposobem, by nie umrzeć. Tam, gdzie istnienie sprowadzone zostało do poziomu zwierzęcej wegetacji, nie ma miejsca na humanizm.

Nierzadko autor ma problemy $\mathrm{z}$ określeniem statusu ontologicznego swoich bohaterów. Trudno bowiem nazwać ludźmi istoty odarte z człowieczeństwa. Instynkt przetrwania zdominował u nich cechy pozostałe - w jednym $\mathrm{z}$ opowiadań Popik protagoniści, Stary i Stara:

upodobnili się do siebie i niczym się nie odróżniał mężczyzna od kobiety, nie przypominali również ludzi i już nimi nie byli. [...] zapomnieli o wszystkich uczuciach, które ich łączyły, i zatracili ludzkie odruchy. Żyli, nienawidząc się i dręcząc, nie umieli bowiem umrzeć ${ }^{38}$.

Apatia Starego i Starej, pokrewna paranoidalnym zachowaniom Pata, ma źródło w świadomości rozpadu jednorodnej wizji rzeczywistości.

Mimo iż nihilizm jest postawą najczęściej deklarowaną przez bohaterów opowieści dark future, nie brak prób jego przezwyciężenia. Soft (znany z fabuły $O b i$, o ba Szulkina), Teodor Hornic (protagonista Głowy Kasandry Marka Baranieckiego), Kirosjan ze Śmierci Szczurołapa Grzędowicza lub przybysz z Bram strachu Popik to postacie reprezentujące tradycyjne wartości (współczucie, przyjaźń, altruizm), nie przystające do realiów świata przedstawionego. Choć postacie owe ponoszą klęskę, w wymiarze etycznym zwyciężają. Pełnią funkcję analogiczną do ,jedynych sprawiedliwych" z kart przedwojennej fantastyki katastroficznej. Dzięki tym bohaterom totalność katastrofy zostaje niejako „zneutralizowana”. Jak wszakże zauważa Krystyna Kłosińska, omawiająca wizje upadku społecznego w utworach z kręgu międzywojennej fantastyki, wspomniana „neutralizacja” stanowi wyłącznie wyraz nadziei i wiary autorów w możliwości zaistnienia indywidualności prometejskiej, która będzie ustawodawcą nowego porządku ${ }^{39}$.

\section{Fascynacja przemocą i jej (nie tylko lekturowe) konsekwencje}

Subkultura punkowa nie zdołała wypracować spójnego stosunku do przemocy. $Z$ jednej strony, odrzucano ja, jako niezgodną $z$ przekonaniami pacyfistycznymi. $Z$ drugiej wszakże - sądzono, iż przemoc skierowana przeciwko członkom wrogich grup i instytucjom państwa (zwłaszcza policji) może być skuteczną metodą samoobrony, zwrócenia uwagi na problemy i podjęcia walki o swoje prawa.

Twórcom dark future obce sa podobne ambiwalencje. Wykreowany przez nich swiat poddany jest imperatywowi przemocy jako jedynego sposobu na rozstrzyganie konfliktów. Gdy nie obowiązują żadne umowy społeczne, stanowi ona tyleż pokusę, ile logiczną konsekwencję braku możliwości znalezienia wyjścia innego niż siłowe. Herosami masowej wyobraźni bohaterów utworów dark future stają się ci,

39 K. Kło sińs ka, Katastroficzna odmiana powieści popularnej. W zb.: Katastrofizm i awangarda. Red. T. Bujnicki, T. Kłak. Katowice 1979, s. 70. 
którzy potrafią wykorzystać agresję do osiagnięcia wymiernych zysków. Oni też w Autobahn nach Poznań Ziemiańskiego stawiani są za wzór innym:

Widziałaś Iwana Dołgorukowa? Był księgowym w Moskwie. Przelazł sam jeden cała pustynię, bez broni i bez zapasów. Jak tu dotarł, to mimo że nie miał pojęcia o wojsku, od razu zrobiliśmy go porucznikiem. Jeśli ktoś wie, jak przeżyć i jak zabijać gołymi rękami, to znaczy, że jest urodzonym żołnierzem i niepotrzebne mu żadne akademie ${ }^{40}$.

Dość często autorzy dark future poświęcają wiele miejsca zabawom w świecie podporządkowanym kultowi siły. Istnieje wręcz osobny, znamienny głównie dla fantastyki anglosaskiej, nurt ukazujący rozrywki przyszłości. Należące doń teksty kultury: filmy (np. Wyścig śmierci 2000, Rollerball ${ }^{41}$ ), utwory literackie (np. Uciekinier i Wielki marsz Stephena Kinga, Siódma ofiara, Pielgrzymka na Ziemię i Cena ryzyka Roberta Sheckleya) oraz gry komputerowe (np. Carpocalypse, Carmageddon), koncentrują się na brutalności owych zabaw ${ }^{42}$. Nawiązujące do nich opowiadanie Mieszka Zagańczyka Freefootball to - w myśl opinii Macieja Parowskiego - „mroczna ekstrapolacja [...] emocji olimpijskich” ${ }^{43}$. Przywołane tu słowa Parowskiego nazbyt jednak dowartościowują utwór epatujacy obrazami bezsensownej przemocy. Fabuła Freefootballu przedstawia perypetie jednego z klubów nowej dyscypliny sportowej, tytułowego freefootballu, będącego połączeniem piłki nożnej z futbolem amerykańskim. Autor nie szczędzi czytelnikowi drastycznych wizji rozgrywek. Oto przykład:

Bobby Miczurin uderzył. Łamany nos Sabonaya chrupnął jak sucha gałązka. Klubowa koszulka Hansy przybrała barwę przeciwnika: na rześką biel siknęła żywa czerwień krwi.

Kibice zawyli w ekstazie ${ }^{44}$.

Celebrowana w przywołanych tu tekstach kultury przemoc zostaje uznana przez bohaterów za element codzienności i włączona w system akceptowanych wartości. Apoteoza gwałtu, przejęta z estetyki znamiennej dla punk rocka i heavy metalu, nie jest jednakże w tym przypadku poddana refleksji. Przemoc w dark future, zwłaszcza w najnowszych utworach, okazuje się celem samoistnym. Autorzy owych obrazów, mimo iż poruszają istotny problem sfery wizualnej dzisiejszego obiegu popularnego, czynią to niejako mimowiednie, nie pogłębiając możliwych wniosków. Tymczasem w tej nowej formie kultury, porównanej z bardziej tradycyjną, „Różnica ilościowa [nasycenia obrazami, m.in. aktów przemocy - A. M.] jest tak wielka, że przekształca się w jakościową: przy rosnącej dawce obrazów zmieniają się proporcje między rodzajami doznań” ${ }^{45}$. W efekcie to, co powinno szokować,

Zi emiańs ki, op. cit., s. 444-445.

Wyścig śmierci 2000 (Death Race 2000). Reż. P. B artel. USA 1975. - Rollerball. Reż. N. J ew is o n. USA 1975.

Zwłaszcza gry komputerowe, $\mathrm{z}$ uwagi na interaktywny charakter rozrywki, eksponuja element przemocy, której odbiorca jest nie tylko świadkiem, ale i współtwórcą. Gracz ma krótki limit czasowy rozgrywki, który może powiększyć (a więc grać dłużej), jeśli dostosuje się do reguł, tj. będzie powodował wypadki i zabijał przechodniów.

mp [M. Pa rowski], notka do: M. Zagań czy k, Freefootball. „Nowa Fantastyka” 1996, nr 8, s. 56.

Za ga ń c zy k, op. cit., s. 52.

J. Fi s ke, Postmodernizm i telewizja. W zb.: Pejzaże audiowizualne. Telewizja, wideo, komputer. Wybór, wstęp, oprac. A. G wó źdż. Kraków 1997, s. 169 (przeł. J. M a ch). 
przyjęte zostaje za normę, a z czasem obojętnieje, gdy nagromadzenie wizji przemocy okazuje się zbyt duże ${ }^{46}$.

Zawieszona między tradycją modernistyczno-międzywojennego katastrofizmu a wymaganiami współczesnej giełdy literackiej ${ }^{47}$, fantastyka dark future skłania się ku „kraksizmowi”. Jest to określenie Parowskiego, które zapewne w najbardziej adekwatny sposób oddaje tendencje w przemianach polskiej science fiction o charakterze katastroficznym. „Kraksizm” staje się swoistym wyrazem deprecjacji filozofii o wydźwięku katastroficznym i jej pauperyzacji, spowodowanej naciskiem na czynnik akcji w obrębie fabuły ukazującej „ostatnie dni ludzkości”. Co znamienne, te same mechanizmy, które miały wpływ na trywializację tendencji katastroficznych, przyczyniły się również do komercjalizacji „krzyku protestu”, jakim u swych źródeł był punk. Dezynwolturę moralną pierwszych utworów (chodzi tu o nowele filmowe Szulkina, opowiadania Popik i Drukarczyka) zastapiła satysfakcja - niekiedy o zabarwieniu sadystycznym - z jaką autorzy prezentują wizje mrocznej przyszłości. Opowiadania te, jak zauważa Parowski, „zdają się nieść przeświadczenie, że okrucieństwo i oszustwo są jedyną rozsądną zasadą w walce wszystkich ze wszystkimi” ${ }^{48}$. Protest przeciw dehumanizacji świata (a tym pierwotnie był punk rock) autorzy ci odczytali jako przyzwolenie na pozbawiona stałych reguł zabawę wartościami. Ich utwory bywają wprawdzie napisane dość sprawnie warsztatowo, jednak nie daja się traktować inaczej niż jako „zabawa w (pseudo)nihilizm”. Przykładem może być Horda Górskiego. Jej lektura uzmysławia dwuznaczność tytułu: jest to bowiem opowieść zarówno o agresywnie zachowującej się grupie ludzi, jak i o wspólnocie żyjącej na wzór koczowników $z$ etapu pierwotnych sposobów organizacji ludności ${ }^{49}$. Jednakże potencjalnie interesująca kwestia socjologiczna - mechanizmy samoistnego odtwarzania się historycznych form społecznych w dobie kryzysu współczesnej cywilizacji - ustępuje miejsca sensacyjno-awanturniczemu potraktowaniu tematu.

Aby uczynić fabułę czytelniczo atrakcyjną, Górski snuje opowieść o grupie rywalizującej z gangami młodzieżowymi. Zdążając do bliżej nie określonego miasta, przedziera się ona przez opuszczone tereny. Kiedy dociera do celu w pościgu za

46 Kwestia ta nie ogranicza się do psychologicznej reakcji na eskalację przemocy, z jaką styka się odbiorca utworów z kręgu dark future. J. M. Ry m k i e w i c z (Umschlagplatz. Paryż 1988, s. 38-39) zauważa, iż podobną prawidłowość można zaobserwować w badaniach nad zbrodnią Holocaustu. Nie jest naszą intencją zestawiać mało ambitną literacką „zabawę w makabrę” ze świadectwami Zagłady. Pragniemy jedynie wskazać na analogiczne skutki wywołane różnymi przyczynami.

Termin „giełda literacka” wprowadził M. C owley (Sztywne okładki czy broszury? W: O sytuacji $w$ literaturze. Przeł. E. Kras n ow ols ka. Warszawa 1969, s. 181), który tym mianem określał „proces przetargów pomiędzy krytykami i rzekomymi krytykami, ustalający pozycję wybitnych autorów w dowolnym miesiącu czy roku”; „Notowania te nie dają odpowiedzi na pytanie, ile egzemplarzy następnej książki danego pisarza uda się sprzedać, bo większość czytelników nie zwraca dużej uwagi na opinie krytyczne. $Z$ drugiej strony, pomagają one ustalić, jacy autorzy będą omawiani w czasopismach literackich i jak obszernie [...], jacy autorzy będą studiowani i naśladowani przez swoich następców w nowym pokoleniu”.

48 M. Parows ki, Czary-mary, punk, BANG! W: Czas fantastyki. Szczecin 1990, s. 323. Określenie „kraksizm” pochodzi z artykułu M. Parows ki e go Katastrofizm czy kraksizm? („Nowa Fantastyka” 1992, nr 3).

Zob. Słownik współczesnego języka polskiego. Red. B. D un aj. Warszawa 1996, s. 309. 
zdrajca, dowiaduje się, że jej wysiłki spełzły na niczym - ten bowiem przybył pierwszy i odsprzedał rządzącym ośrodkiem znalezisko wykradzione protagonistom ${ }^{50}$, które miało stać się ich kartą przetargową w negocjacjach o przyznanie obywatelstwa. Po opuszczeniu murów niedostępnego dla siebie miasta, grupa kieruje się do mijanej wcześniej osady. W akcie zemsty członkowie hordy zamierzają ją spalić, jednak po przybyciu na miejsce widzą zgliszcza i stacjonujace wojsko; w starciu z nim część bohaterów ginie. Oto dalsze losy pozostałych:

Szli cały dzień, rzadko odpoczywając. Nie spotkali żadnego kupca, rolnika, nawet patrolu. W ogóle nie spotkali nikogo.

Wieczorem rozpalili olbrzymie ognisko. Usiedli wokół niego kręgiem. Znowu było ich mniej ${ }^{51}$.

Utworami typowymi dla obecnego kształtu dark future sa opowiadania Ognie $w$ ruinach i Alpha Team Szmidta. Pierwsze z nich prezentuje losy lekarza, który zmobilizowany i przeniesiony do koszar ukrytych pod Ślężą - przeczekał wojnę atomową. Kiedy po dwu latach zostaje wysłany na zwiad, trafia do niewoli ofiar konfliktu nuklearnego. Skazani na śmierć wskutek choroby popromiennej mieszkańcy Wrocławia tworzą nowa mitologię. Według niej do kataklizmu atomowego przyczyniła się grupa polityków dążąca do zaspokojenia ambicji imperialnych. Zwani Wyklętymi, pełnią oni funkcję demonów nowego świata. Jan Sobieszczuk, charyzmatyczny przywódca opisanej zbiorowości, wykorzystuje pogłoskę o winie polityków do własnych celów, by odbudować struktury państwowe, na których czele staje jako burmistrz Wrocławia ${ }^{52}$.

Ognie $w$ ruinach można traktować jako próbę wyzyskania stereotypowej scenerii do ukazania sytuacji człowieka ery postapokaliptycznej. Tymczasem Alpha Team to jedynie zbiór trudniej lub łatwiej rozpoznawalnych clichés; świadomość ich występowania wspomaga wprawdzie lekturę utworu, lecz nie warunkuje jego zrozumienia. Tytułowy Alpha Team jest drużyną zawodowych morderców, strzegacych wybrzeży Australii przed nielegalnymi imigrantami z rejonów świata objętych skażeniem w wyniku wybuchu epidemii. Wykorzystany przez Szmidta pomysł sugeruje jawne związki tekstu $\mathrm{z}$ popularna $\mathrm{w}$ kręgach miłośników fantastyki gra komputerową Resident Evil ${ }^{53}$. Opowiadanie stanowi jednak bardziej parafrazę niż

W opowiadaniu nie jest doprecyzowane, o jakie znalezisko chodzi. Jedyne, czego dowiaduje się na jego temat czytelnik, to informacja, iż jest nim „Amulet, relikt przeszłości, źródło władzy magicznej czy też niezwykle rzadki minerał, potrzebny do produkcji nowej generacji głowic chemicznych [...]" (G ó r s ki, op. cit., s. 52).

51 Ibidem, s. 56.

52 Nawiąujące do utworu Szmidta opowiadanie Ziemiańskiego Autobahn nach Poznań prezentuje podobną wizję upadku świata. Wojnę atomową poprzedziły w tym świecie eksperymenty klimatyczne i genetyczne. Zbiorowym bohaterem jest grupa najemników osłaniająca drogę konwojów z Poznania do Wrocławia. Podobnie jak w przypadku wcześniejszej powieści tego autora, Dziennika czasu plagi, Autobahn nach Poznań epatuje opisami niewybrednych żartów i zachowań społeczności żyjącej w zniszczonym świecie.

53 Akcja gry toczy się w Racoon City - mieście opanowanym przez śmiercionośny wirus, zmieniający ludzi w zombi. Porządek usiłuje przywrócić organizacja S.T.A.R.S. i zatrudnieni przez nią najemnicy. Zadanie gracza polega na zdobyciu jak największej liczby punktów za każdego zabitego wroga, pozwalającym na rozwijanie umiejętności kierowanej postaci. W powszechnej opinii jest to produkcja bardzo brutalna, epatująca scenami mordów - w nieformalnej klasyfikacji Resident Evil 
nowelizację tej gry. Jego akcja nawiązuje również do powieści Nevila Shute'a Ostatni brzeg, oraz do filmu Epidemia ${ }^{54}$. Przygody tytułowej drużyny rozgrywają się $\mathrm{w}$ świecie opanowanym przez śmiercionośny wirus ( $\mathrm{nb}$. Resident Evil jest ulubiona grą bohaterów). Podobnie jak w przypadku Apokalipsy według Pana Jana, zakończenie Alpha Team pozostaje otwarte, sugerując, że może pojawić się kontynuacja.

Jaka przyszłość czeka fabuły spod znaku fantastyki mrocznej przyszłości? W pewnej mierze odpowiedź na to pytanie dają losy subkultury punkowej. Pierwotnie kontestująca mechanizmy kultury popularnej, wkrótce subkultura ta została przez nią zasymilowana i jeżeli obecnie niektórzy twórcy (np. zespół Offspring) sięgają do tradycji punk rocka, czynią to ze względów jedynie komercyjnych. Równie komercyjny wymiar zyskała fantastyka dark future. Jeśli miała niegdyś ambicje pełnienia analogicznej funkcji, co punk rock w kulturze i muzyce rockowej, należą one dziś do przeszłości. Ograniczenia tego nurtu science fiction nie wynikaja jedynie $z$ zaliczania fantastyki naukowej do kręgu kultury popularnej. Wszak, jak zauważa Lem:

Co czynią rozmiary zewnętrznej klęski? Łagodzą wyrok zawisający nad jej aktorami. Obezradniają [!] nas zatem. Powodują, że już nie potrafimy rozróżniać pomiędzy katastrofą „zewnętrzną” - świata padającego, i „wewnętrzną” - jego ludzi. Pozostają tylko jakości „czystej grozy”. Ale nie można też straszyć zbyt często tym samym zjawiskiem - dochodzi do przyzwyczajenia. [...] To, co kiedyś było wizja, innowacją, mitem [...], a potem otrzymało szansę ostrzeżenia, staje się zabawą, która nuży ${ }^{55}$.

Mroki przyszłości, tak chętnie przedstawiane przez twórców dark future, okazały się zaledwie nową aktualizacją dawnych obaw ludzkości.

Abstract

ADAM MAZURKIEWICZ University of Łódź

DARKNESS OF THE FUTURE ON SO-CALLED DARK FUTURE TREND IN SCIENCE-FICTION

The article shows that science-fiction writers oftentimes resort to the myth of progress due to which their creativity tends to be seen as a fictionalised form of reflection over the possible forms of civilisation development. Most often the writers for the most part limit their visions to axiologically ambivalent images of future subjected to the dictate of omnipresent technology. At times, of which dark future pieces of literature is the evidence, the technology itself becomes the cause of fall of human societies. In the stories included into the trend, the motif of extermination is a self-contained value, the novelists often reach for the motifs of threat rooted in technology only for enjoyment. As a result, the pieces are first and foremost a source of escapist play due to which social and civilisational fears of humanity are actualised and degraded.

określa się najczęściej mianem tzw. strzelanki (pojęcie oboczne do terminu „strzelanina”; na temat nazewnictwa gatunków gier komputerowych zob. np. S. Łuka s z, Magia gier wirtualnych. Warszawa 1998), czyli gry polegającej na eliminacji wszystkich przeciwników w dowolny sposób. Szerzej na temat tej produkcji zob. M. Marzę cki, Resident Evil. „SFinks” 2002, nr 7/8. 